音声言語医学 $54: 8-13,2013$

原 著

\title{
陳旧性一側喉頭麻疩に対する披裂軟骨内転術と 神経移行術の併用術の経時的効果
}

\author{
兒玉 成博 讃岐 徹治 湯本 英二
}

\begin{abstract}
要 約: 一側喉頭麻痺の嗄声に対する外科的治療には, 甲状軟骨形成術 I 型, 声帯内注入術, 披裂軟骨内転術, 神経再建術がある。今回, 陳旧性一側喉頭麻痺に対し, 披裂軟骨内転術に併 用して神経移行術を行った症例の術後発声機能を経時的に検討した。検討項目は, 声帯振動の 規則性, 振幅, 声門間隙, 空気力学的検査 (MPT, MFR), 聴覚心理的評価の GRBAS 尺度 (G, B）である。検討は，術前および術後 1，3，6，12，24 カ月と経時的に評価した。結果，術前 後では, MFRの術後 1 カ月の值を除いたすべての項目・時期で有意に改善した。また，術後 経時的に比較すると, 声帯振動の振幅, 声門間隙, MPT, G, B が術後 1 カ月以降も経時的に 改善した。陳旧性一側喉頭麻瘏に対して, 内転術と神経移行術の併用を行うと, 発声機能が術 前後で改善するだけでなく, 術後も経時的な改善を認め, ほぼ正常声になることが明らかとなっ た.
\end{abstract}

索引用語：一側喉頭麻瘏, 披裂軟骨内転術, 神経移行術, 声帯振動, 経時的評価

\section{Longitudinal Follow-Up Arytenoid Adduction and Ansa Cervicalis Transfer with Unilateral Vocal Fold Paralysis}

\author{
Narihiro Kodama, Tetsuji Sanuki and Eiji Yumoto
}

\begin{abstract}
Vocal fold (VF) injection, thyroplasty type I and arytenoid adduction (AA) are common treatments for breathy dysphonia due to unilateral VF paralysis (UVFP). However, some patients do not recover their normal voices following these procedures. Theoretically, reinnervation of the thyroarytenoid (TA) muscle is the ideal treatment for UVFP. Normal voice production requires optimal closure of the glottis with median location of the VFs, symmetrical VF tension and mass, and supple mucosa. In the present study, we evaluated the long-term efficacy of AA combined ansa cervicalis-recurrent laryngeal nerve anastomosis (ACN-RLN) in the treatment of UVFP. Eight patients with severe paralytic dysphonia with large glottic gap were included. Vocal outcome was followed up over 24 months to evaluate the long-term efficacy of this combined procedure. Videostroboscopy, aerodynamic analysis, acoustic analysis, and perceptual voice quality were evaluated preoperatively and postoperatively at $1,3,6,12$ and 24 months. All parameters improved significantly after surgery and continued to improve over the 24-month period. Treatment with AA+ACNRLN provided near-normal vocal function in the 24-month follow-up. Therefore, this method
\end{abstract}

熊本大学耳鼻咽喉科・頭頸部外科：=860-8556 熊本市中央区本荘 1-1-1

Department of Otolaryngology-Head and Neck Surgery, Graduate School of Medicine, Kumamoto University: 1-1-1 Honjo, Chuo-ku, Kumamoto, 860-8556, Japan 2012 年 5 月 30 日受稿 2012 年 7 月 12 日受理 
could be a successful surgical treatment for severe paralytic dysphonia.

Key words: unilateral vocal fold paralysis, arytenoid adduction, ansa cervicalis-recurrent laryngeal nerve, videostroboscopy

\section{はじめに}

一儧喉頭麻瘏の嗄声に対する外科的治療は，声帯の 体積を増やす方法として甲状軟骨形成術 I 型1)（以下， I 型）や声帯内注入術2)，声带を内転させる方法とし て披裂軟骨内転術3) (以下, 内転術）がある。また， 麻疩した内喉頭筋に対し，神経再支配を目指す方法と して神経再建術があり，反回神経の断端どうしを縫合 する神経縫合術，反回神経断端を利用できるが直接縫 合できないときに大耳介神経などを間置する神経移植 術，反回神経中枢側を利用できないときに頸神経ワナ と反回神経末梢側を縫合する神経移行術などがあ

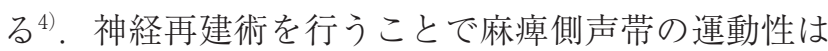
回復しないが, 筋萎縮の進行を防止し, 回復させるこ とが知られている。

これまで，陳旧性一側喉頭麻痺に対する外科的治療 の効果は報告されてきた．Kimuraら ${ }^{5)}$ は，内転術後 に声带内注入術を追加した 40 名の術後発声機能を検 討し, 平均值は, 最長発声持続時間（Maximum Phonation Time \{以下 MPT\} 単位: 秒) 15 秒, 平均 発声時呼気流率 (Mean air Flow Rate \{以下 MFR 単位: $\mathrm{m} l$ /秒) $223 \mathrm{~m} l /$ 秒と正常值より少し高めであり, 聴覚印象では軽度の嗄声を認めたと報告した。湯本 $ら^{6)}$ は, 一側喉頭麻痺症例 61 名に対して嗄声の改善 を目指して, I 型, 内転術, 内転 + I 型, 内転十声带 内注入術を行い, どの術式でも発声機能の改善が得ら れたが，MPT 10 秒未満，MFR $200 \mathrm{~m} l$ 秒以上と正 常值まで改善しなかった例が約半数を占め, 従来の静 的な再建術のみでは, 麻痺声帯の自然な緊張と声帯の
体積を回復することができないと報告している。一方， われわれは内転術と神経移行術を併用した 9 例の空気 力学的検查 (MPT), 音響分析 (HNR), 声域, 聴覚 心理的評価の GRBAS 尺度（G，B）について検討し， 術前後で発声機能が改善するだけでなく術後も経時的 に音声が改善し, 正常声へ近づくことを報告した ${ }^{7)}$. しかし, 声帯振動の術後変化について評価を行ってい ないため，今回，陳旧性一側喉頭麻瘏に対して内転術 と神経移行術を併用した症例の声带振動の評価を含め た術後発声機能について経時的に検討したので報告す る。

\section{対象と方法}

対象は, 2001 年 10 月から 2008 年 11 月までの間に 熊本大学耳鼻咽喉科・頭頸部外科で一側喉頭麻疩と診 断され，内転術と神経移行術を併用した 11 例のうち， 術後に食道癌の再発を認めた 1 例と術後出血を生じ止 血術を追加した 2 例を除いた計 8 例とした. 男性 4 例, 女性 4 例で, 平均年齢は 46.5 歳（標準偏差 12.8 歳） であった。対象の詳細を表 1 に示す。

手術適応は，麻疩側声帯の固定位置が中間位あるい は外転位にある症例や発声時の両側声帯のレベル差が ある症例かつ反回神経の末梢側が確認でき，麻痺側も しくは健側の頸神経ワナが麻疩側反回神経末梢断端と 十分縫合が可能な場合に内転術と神経移行術を併用し た。

原因疾患は, 後頭蓋窩髄膜腫術後, 椎骨動脈瘤術後, 頸部腫瘤術後，球麻痺による一側喉頭麻痺症例がそれ ぞれ 1 例と大動脈瘤術後, 縦隔腫瘍術後がそれぞれ 2

表 1 対象症例

\begin{tabular}{llllcc}
\hline 症例 & 性 & 年齢 & 麻痺側 & $\begin{array}{c}\text { 麻疩発症から手術 } \\
\text { までの期間 (月) }\end{array}$ & 原因疾患 \\
\hline (1) & 女 & 60 & 左 & 28 & 後頭蓋窩髄膜腫術後 \\
(2) & 男 & 31 & 右 & 6 & 椎骨動脈瘤術後 \\
(3) & 女 & 49 & 右 & 54 & 頸部腫瘤術後 \\
(4) & 女 & 49 & 右 & 12 & 縦隔腫瘍術後 \\
(5) & 男 & 59 & 左 & 8 & 大動脈瘤術後 \\
(6) & 男 & 33 & 左 & 45 & 大動脈瘤術後 \\
(7) & 男 & 59 & 左 & 8 & 縦隔腫瘍術後 \\
(8) & 女 & 32 & 左 & 27 & 球麻瘏 \\
\hline
\end{tabular}




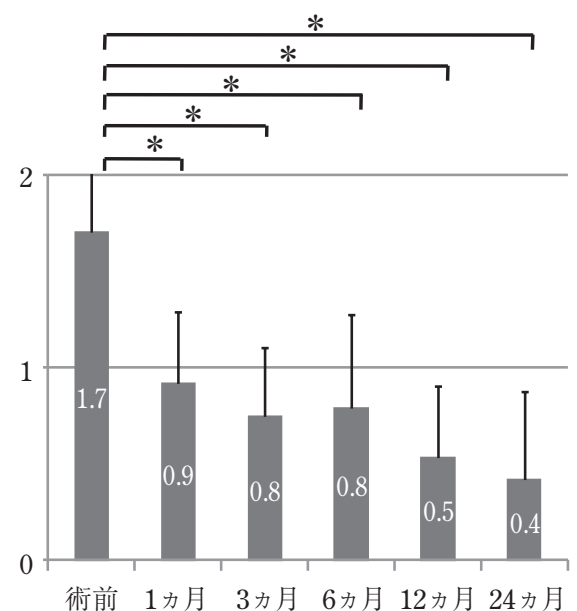

規則性

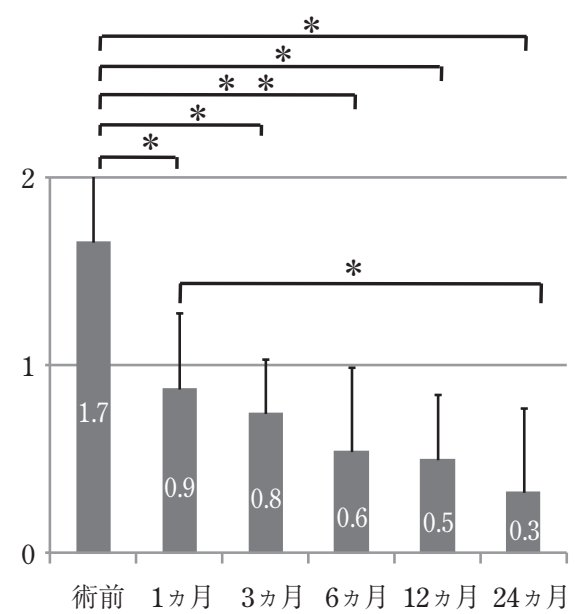

振幅

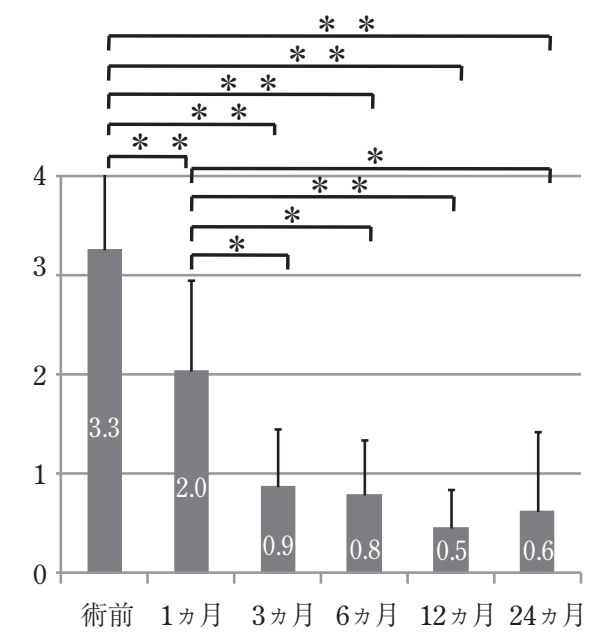

声門間隙

図 1 声帯振動の経時的評価

Mann Whitney U-test, ${ }^{*} \mathrm{p}<0.05, \quad * * \mathrm{p}<0.01$

例であった。手術は, すべて全身麻酔下で施行し, 症 例118は下位脳神経麻瘏を合併し嚥下障害を認め, 同 時に輪状咽頭筋切断術, 梨状陥凹縫合術を行った。 症 例(6) は，喉頭棵組み手術（内転術とI 型を併用）の 2 年後に気息性嗄声が再度出現したため再手術として内 転術と神経移行術を行った。麻痺発症から手術までの 期間は 6 力月から 54 カ月で, 平均 23.4 力 (標準偏 差 18.4 カ月, 中央值 20 カ月) であった.

発声機能評価として, 声帯振動の評価, 空気力学的 検査, 聴覚心理的評価を行った.

\section{1 . 声帯振動の評価}

声帯振動の観察には, 喉頭ストロボスコピーを用い た、ストロボスコープは, LS-3A (永島社製) あるい は Pulsar 20140020 (カールストルツ社製）を用い, 喉頭の観察は, CCD カメラ MV-596（ストライカー 社製)に接続した斜視型硬性内視鏡 SFT-1 (永島社製) あるいは電子内視鏡 $\mathrm{EPK}-1000$ (ペンタックス社製) とビデオ鼻咽喉スコープ VNL1171K（ペンタックス 社製）を用いた。母音/e/あるいは/i/の無関位およ び高音発声時のストロボ像をデジタルビデオ DVCPRO AJ-D230H（パナソニック社製）に音声と ともに記録した。

母音/e/あるいは/i/の無関位発声時の動画を用い て声帯振動の規則性, 振幅, 声門間隙を評価した。評 価は, 3 名の耳鼻咽喉科医と 1 名の言語聴覚士で評価 し, 平均值を採用した。 また, 4 名の判定結果が 2 段 階以上異なるときは，1段階以内の相違になるまで再 度評価を行った，規則性 $(0$ ：規則的であり，対称で ある，1：規則的であるが，非対称である，2：不規則
である) と振幅（0：粘膜波動があり, 健側声带と振 幅が同じ．1：粘膜波動があり, 健側声帯に比べて振 幅が小さい，2：粘膜波動がない）は，3 段階で評価 した。声間間隙は, Yumotoら ${ }^{8)}$ の報告に準じて, 5 段階（0：間隙なし. 1 : 声帯膜様部にわずかに間隙が ある. 2 : 声帯膜様部約 $1 / 3$ に間隙がある. $3:$ 声帯膜 様部約 $2 / 3$ に間隙がある. 4 : 声帯が接触しない) で 評価した。

\section{2. 空気力学的検査}

空気力学的検査は, 声の検査法 ${ }^{9)} に$ 準じて MPT, MFR を評価した，MPTの測定は，ストップウォッ チを用い, MFRの測定は, 発声機能検査装置 PS$77 \mathrm{E}$ (永島社製) を用いた。

\section{3. 聴覚心理的評価}

GRBAS 尺度を用い, 声の検査法9)に準じて検査を 行った。耳鼻咽喉科専門医 2 名と言語聴覚士 1 名で評 価し, 平均値を採用した。一側㑨頭麻疩の嗄声の特徵 である気息性嗄声に関与する $\mathrm{G}$ と B を今回検討した。

検討時期は, 術前および術後 $1 ， 3 ， 6 ， 12 ， 24$ 力月 と経時的に検討した. 比較の方法は, 術前後の比較, 術後の経時的な比較を行い, 統計学的検討として空気 力学的検査には unpaired t-test, 声带振動評価と聴覚 心理的評価には Mann Whitney U-testを用いた.

\section{結果}

\section{1. 声帯振動}

結果を図 1 に示す, 術前後の比較では, 規則性, 振 幅, 声門間隙ともに術前と術後 1 カ月以降のすべての 時期で有意に改善した. 術後経時的な比較では, 振幅 

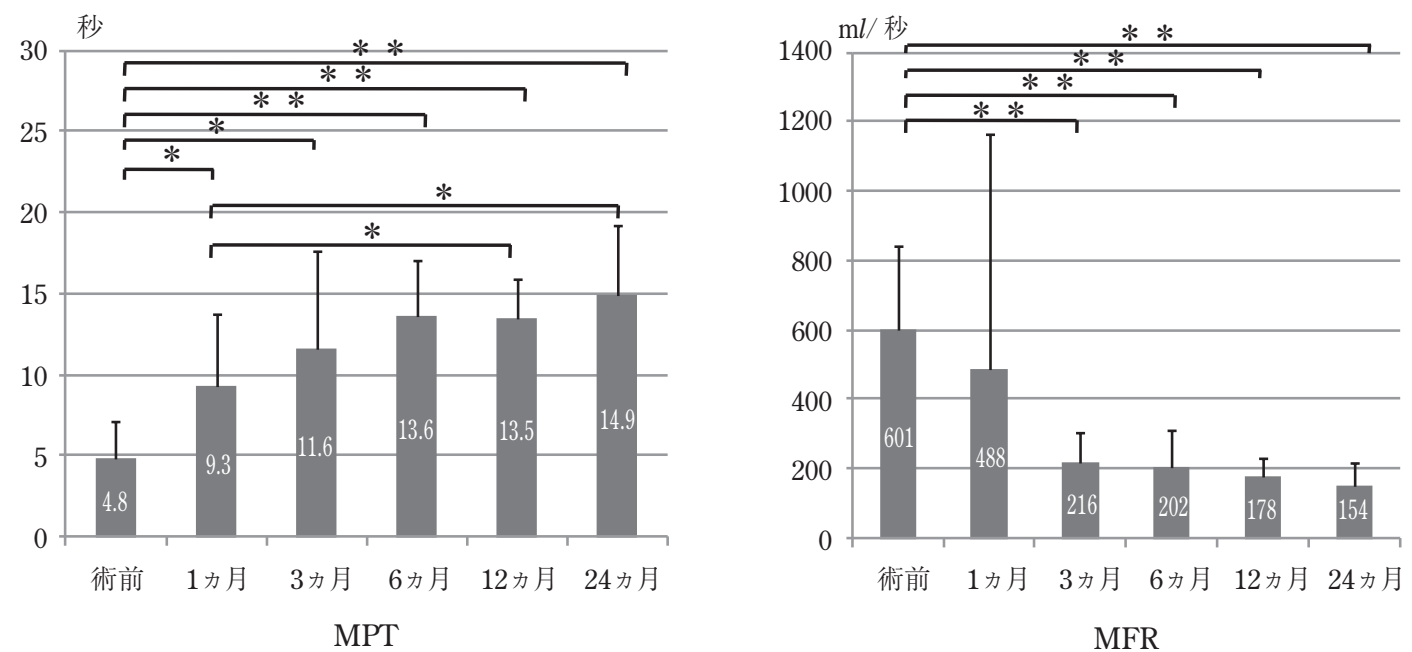

図 2 空気力学的検査の経時的評価 Unpaired t-test, ${ }^{*} \mathrm{p}<0.05, \quad * * \mathrm{p}<0.01$
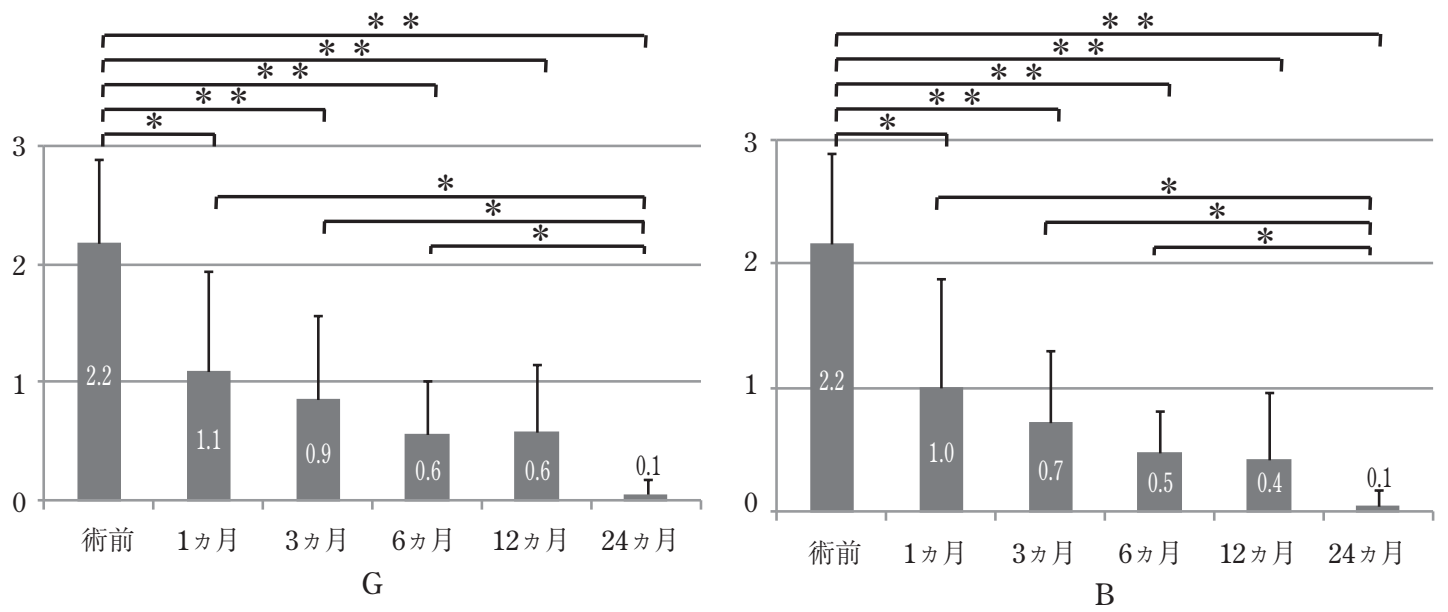

図 3 聴覚心理検査の経時的評価

Mann Whitney U-test, ${ }^{*} \mathrm{p}<0.05, \quad{ }^{* *} \mathrm{p}<0.01$

の術後 1 カ月の值に比べ, 術後 24 力月の值が有意に 改善した。また，声門間隙の術後 1 カ月の值に比べ, 術後 3，6，12，24 カ月の值が有意に改善した。規則 性では，術後有意な改善は認めなかった。術後 24 カ 月の規則性，振幅，声門間隙の值は，いずれも 1.0 以 下となった。

\section{2 . 空気力学的検査}

結果を図 2 に示す。術前後の比較では, MPTは, 術前と術後 1 力月以降のすべての時期で有意に改善し た. MFR は，術前と術後 3 カ月以降のすべての時期 で有意に改善した，術後経時的な比較では，MPTの 術後 1 力月の值に比べ，術後 12,24 力月の值が有意 に延長していた，MFRでは，術後有意な改善は認め なかった，術後 24 カ月の MPT, MFRの值は, 10 秒 以上, $200 \mathrm{ml} /$ 秒以下となり, 正常範囲まで改善した.

\section{3. 聴覚心理的評価}

結果を図 3 に示す。術前後の比較では，G，B とも に術前と術後 1 力月以降のすべての時期で有意に改善 した。術後経時的な比較では，G，Bの術後 24 カ月 の值が術後 $1,3,6$ カ月の值に比べて有意に改善した.

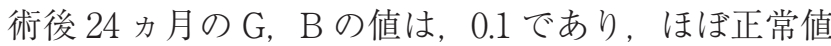
となった。

\section{考察}

一側喉頭麻痺では, 麻痺側声帯の運動が障害され, 甲状披裂筋が発声時に収縮しないため声带縁が弓状に なり，発声時声門閉鎖不全をきたす。また，反回神経 の傷害後に部分的な神経再支配が起こった場合でも, 再生神経線維の過誤支配により声帯運動は回復しない ことが多い。さらに，健側声帯と麻痺側声帯の質量差 
から声帯振動が不規則になり，位相差を生じることが あることから，一側喉頭麻瘦による嗄声の評価で声帯 振動の評価は重要である。

これまで, 陳旧性一側喉頭麻痺に対する神経再建術 後の喉頭ストロボスコピー評価を用いた声帯振動の検 討は，わずかながら報告されてきた。 Wangら ${ }^{10)}$ は, 一側喉頭麻痺に神経移行術を行った 56 例を対象に, 喉頭ストロボスコピー評価（声門間隙，麻痺側声带の 固定位置, 声带振動の規則性, 対称性), 空気力学的 検査 (MPT), 音響分析 (Jitter, Shimmer, NHR), 聴覚心理的評価（GRBAS 尺度）を行い, 術前と術後 2 年以上経過時で有意に改善を認めたと報告してい る. また, Leeら ${ }^{11)}$ も陳旧性一唄喉頭麻瘏に対して神 経移行術を行った 15 例を対象に, 喉頭ストロボスコ ピー評価（声門間隙，仮声帯の過内転，麻瘏側声帯の 固定位置）を行い，術前後で有意に改善したと報告し ている. Crumleyら ${ }^{12)}$ は, 一側喉頭麻疩に対して神経 移行術を行った 2 症例の術後声帯振動を評価し, 左右 対称になったと報告している。このように，喉頭スト ロボスコピーを用いた声帯振動の評価で, 術前後の比 較は行われてきたが，術後経時的に検討した報告はな かった。 われわれの検討では, 声帯振動の規則性, 振 幅, 声門間隙が術前と術後 1 力月以降のすべての時期 で有意に改善し, 振幅と声門間隙は, 術後 1 力月以降 も経時的に改善することが明らかとなり, 術後 24 力 月の規則性, 振幅, 声門間隙の值は, いずれも 1.0 以 下まで改善した。

声帯振動に加えて, 空気力学的検查では, MPT で 術前と術後 1 力月以降のすべての時期で有意に改善 し, 術後 1 カ月以降も経時的に延長した. MFR で術 前と術後 3 カ月以降のすべての時期で有意に改善し た。また，聴覚心理的評価では，G，Bともに術前と 術後 1 カ月以降のすべての時期で有意に改善し, 術後 1 力月以降も経時的に改善した。ささらに, 術後 24 力 月の発声機能を正常值と比較すると, 術後 24 力月の MPT，MFR は 10 秒以上， $200 \mathrm{ml}$ 秒以下， G と B は 0.1 となり, ほぼ正常音声まで改善した。

今回の検討で, 術前に比べ, 術直後 (術後 1 力月も しくは術後 3 カ月）から発声機能が改善した理由は, 内転術を施行したことで発声時の声門間隙と声带のレ ベル差を軽減できたためと考える。しかし, 内転術単 独施行例の術後経過を追うと術後の声帯浮腫が軽快す ることや声帯萎縮の進行により，音声が悪化する例を 認めることがある. 山形ら ${ }^{13)}$ は, 内転術, 内転 + I 型, 外側輪状披裂筋牽引固定術について比較し, 術後経過
を追うと, 術後 1 年を過ぎた頃より声带萎縮の進行を 認め, 術後 16 力月に追加手術を行ったと報告してい る.

今回, 発声機能が術前後で改善するのみならず, 声 帯振動の振幅, 声門間隙, MPT, G, B では, 術後 1 力 月以降も経時的に改善しており，これは，神経移行術 を併用したことにより，甲状披裂筋の神経再支配が起 こり，術後時間が経過するにつれ発声時の甲状披裂筋 の筋緊張を再獲得してきたことと，甲状披裂筋の萎縮 が回復してきたためと考える。Zhengら ${ }^{14)}$ は, イ又の 脱神経した内喉頭筋を用いて神経移行術, 神経挿入術 (靧神経ワナの分枝を内転と側筋に挿入)，神経筋弁移 植術（頸神経ワナを用いて内筋と側筋に移植）を行い, 脱神経後 8〜10 カ月以内に神経再建術を施すと筋の萎 縮や線維化がないことを組織学的に明らかにしてい る.

神経移行術の効果が現れてくる時期に関して, Lorenz $\check{5}^{15)}$ は, 麻痺発症平均 12 力月を経た患者に神 経移行術を行い, 経過観察した 38 名中 37 名で, 平均 して術後 4 カ月で音声が改善し出したと報告してい る。また, Maronianら ${ }^{16)}$ は, 神経移行術あるいは神 経筋弁移植術を行い, 術後 6 週から 7 力月で音声の改 善が見られるようになり, 術後 1 年で最大効果が得ら れたと報告している。 今回の検討では, 神経移行術と 内転術を併用しており, 内転術の効果により術直後 (術 後 1 力月もしくは術後 3 力月） から発声機能が改善, さらに神経移行術の効果により術後 1 カ月以降も経時 的に発声機能が改善し, どの検討項目でも術後 12 力 月から 24 カ月で最も良好な值となった。

今回の検討は症例数が 8 例と少なく, 今後症例数を 増やして検討する必要がある。また，甲状披裂筋の筋 緊張と筋萎縮を評価するためには，喉頭ストロボスコ ピー評価のみでは不十分である。甲状披裂筋の発声時 の筋緊張は，筋電図を用いて評価する必要がある。ま た，甲状披裂筋萎縮の改善を評価するために 3 次元 $\mathrm{CT}$ 内視法 ${ }^{17)}$ により麻痺側声帯の厚みを評価する必要 がある。

\section{まと め}

陳旧性一側喉頭麻瘦に対して, 内転術と神経移行術 の併用術を施行した 8 例の術後発声機能を経時的に評 価した。発声機能評価として, 喉頭ストロボスコピー による声帯振動の評価, 空気力学的検査, 聴覚心理的 評価を行った. 術前後, すべての項目で有意に改善し, 声带振動の振幅と声門間隙, MPT, G, B は, 術後 1 力 
月以降も経時的に改善を認めた。内転術と神経移行術 を併用することで, 発声機能が術直後より改善し, 術 後も経時的に改善することでほぼ正常声になることが 明らかとなった。

\section{文献}

1) Isshiki $\mathrm{N}$, Morita $\mathrm{H}$, Okamura $\mathrm{H}$, et al: Thyroplasty as a new phonosurgical technique. Acta Otolaryngol, 78: 451457, 1974.

2) Tamura E, Fukuda H, Tabata $Y$, et al: Use of the buccal fat pad for vocal cord augmentation. Acta Otolaryngol, 128: 219-224, 2008.

3) Isshiki N, Tanabe M and Sawada M: Arytenoid adduction for unilateral vocal cord paralysis. Arch Otolaryngol, 104: 555-558, 1978.

4) Miyauchi A, Matsusaka K, Kihara M, et al: The role of ansa-to-recurrent laryngeal nerve anastomosis in operations for thyroid cancer. Eur J Surg, 164: 927-933, 1998.

5) Kimura M, Nito T, Imagawa $H$, et al: Collagen injection as a supplement to arytenoids adduction for vocal fold paralysis. Ann Otol Rhinol Laryngol, 117: 430-436, 2008.

6）湯本英二, 中野幸治, 小山田幸夫, 他：声带麻痺に対する 喉頭枠組み手術一現状および問題点とその対策. 頭頸部外 科, $11: 83-89,2001$.

7) Hassan MM, Yumoto E, Bakara MA, et al: Vocal outcome after arytenoid adduction and ansa cervicalis transfer. Arch Otolaryngol Head Neck Surg, 138: 60-65, 2012.

8) Yumoto E, Sanuki T and Kumai Y: Immediate recurrent laryngeal nerve reconstruction and vocal outocome. Laryngoscope, 116: 1657-1661, 2006.

9) 日本音声言語医学会編：新編 声の検査法, 医歯薬出版, 東京, 136-149 頁, 2009.
10) Wang W, Chen S, Chen D, et al: Contralateral ansa cervicalis-to-recurrent laryngeal nerve anastomosis for unilateral vocal fold paralysis: a long-term outocome analysis of 56 cases. Laryngoscope, 121: 1027-1034, 2011.

11) Lee WT, Milstein C, Hicks D, et al: Results of ansa to recurrent laryngeal nerve reinnervation. Otolaryngol Head Neck Surg, 136: 450-454, 2007.

12) Crumley $R$ and Izdebski $K$ : Voice quality following laryngeal reinnervation by ansa hypoglossi transfer. Laryngpscope , 96: 611-616, 1986.

13）山形和彦, 兵頭政光, 本吉和美, 他：一側声帯麻痺に対す る音声外科手術施行後の追加掞よび再手術例の検討. 耳鼻, $50: 395-399,2004$.

14) Zheng H, Zhou S, Chen S, et al: An experimental comparison of different kinds of laryngeal muscle reinnervation. Otolaryngol Head Neck Surg, 119: 540-547, 1998.

15) Lorenz RR, Esclamado RM, Teker AM, et al: Ansa cervicalis-to-recurrent laryngeal nerve anastomosis for unilateral vocal fold paralysis: Experience of a single institution. Ann Otol Rhinol Laryngol, 117: 40-45, 2008.

16) Maronian N, Waugh P, Robinson L, et al: Electromyographic findings in recurrent laryngeal nerve reinnervation. Ann Otol Rhinol Laryngol, 112: 314-323, 2003.

17) Yumoto E, Nakano $K$ and Oyamada Y: Relationship between 3D behavior of the unilaterally paralyzed larynx and aerodynamic vocal function. Acta Otolaryngol, 123: 274-278, 2003.

別刷請求先 : = 860-8556 熊本市中央区本荘 1-1-1 熊本大学耳鼻咽喉科 · 頭頸部外科 兒玉成博 